\title{
Monoclonal Antibody CEP-37250/KHK2804
}

National Cancer Institute

\section{Source}

National Cancer Institute. Monoclonal Antibody CEP-37250/KHK2804. NCI Thesaurus.

Code C98296.

A humanized monoclonal antibody targeting glycolipids, with potential

immunomodulating and antineoplastic activity. Upon administration, monoclonal

antibody CEP-37250/KHK2804 targets and binds to a specific tumor antigen, thereby

stimulating the immune system to exert an antibody-dependent cellular cytotoxicity

(ADCC) against the tumor associated antigen (TAA)-expressing cancer cells. This agent has shown to be active in both wild-type and mutant K-RAS-expressing colorectal cancer cells. 